Humanitarian

Engineering and Energy

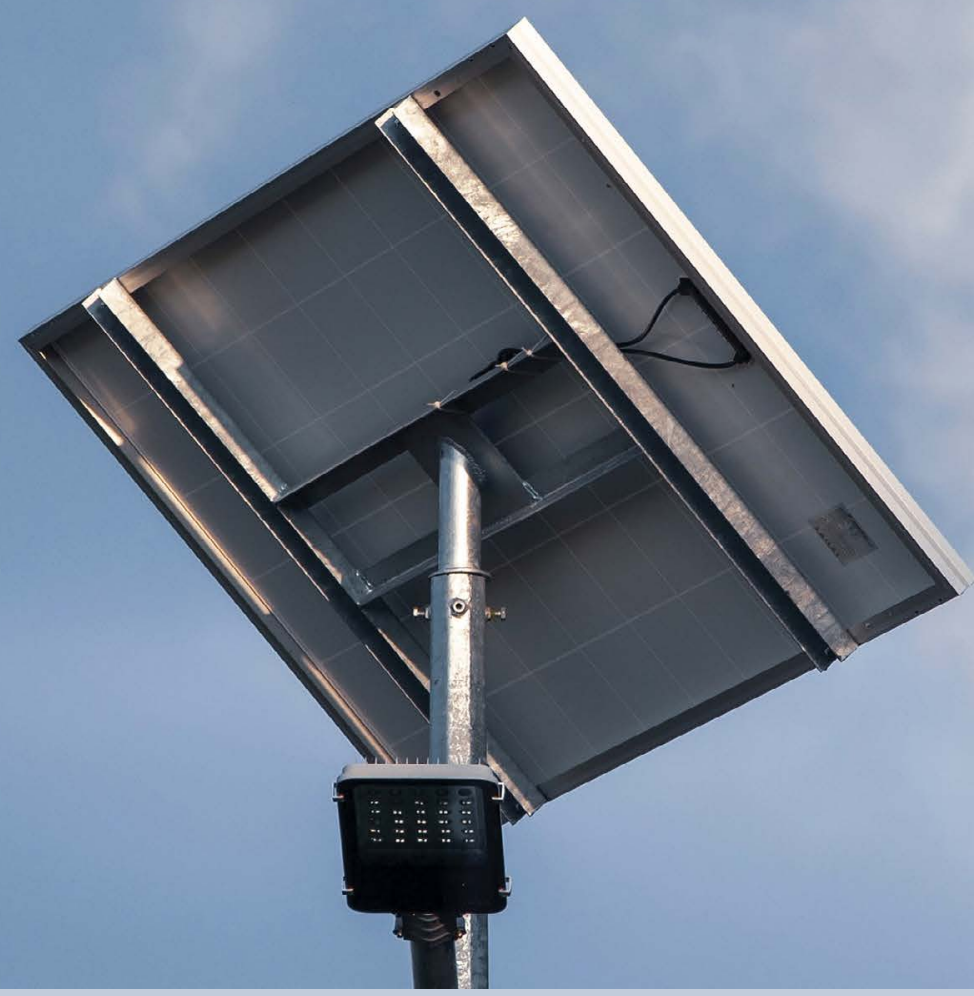

\title{
Definitions and differences: The evolving space of humanitarian energy access
}

Hajar Al-Kaddo \& Sarah Rosenberg-Jansen | June 2021 


\section{Acknowledgements}

The authors would like to acknowledge the financial support of the Engineering and Physical Science Research Council (EPSRC) for funding the Humanitarian Engineering and Energy for Displacement (HEED) project as part of the Global Challenges Research Fund (EP/P029531/1). We would also like to recognise the support of the Global Platform of Action, Chatham House, and the RE4R (Renewable Energy for Refugees) Project (a partnership between Practical Action and UNHCR, supported by the IKEA Foundation).

The paper has attempted to provide an overview of some of the current definitions and core concepts in the humanitarian energy sector as relevant in 2021. For further discussion, please reach out to Hajar Al-Kaddo, Sarah Rosenberg-Jansen, or the Global Platform for Action (GPA).

Thanks to Thomas Fohgrub, Aimee Jenks, Jonathan Archimi, Sadiq Zafrullah, Owen Grafham, James Haselip, Iwona Bisaga, Philip Sandwell, Peter Thomas, Sam Williamson, Eva Mach, Florent Eveille, and Elena Gaura and the HEED project, for inputting to the concepts underpinning this paper. Hajar Al-Kaddo also wishes to thank colleagues at Centre for Humanitarian Action, University College Dublin.

\section{Authors}

- Hajar Al-Kaddo | Coventry University

- Sarah Rosenberg-Jansen | University of Oxford

Author contact information: Hajar.Al-Kaddo@ucdconnect.ie and Sarah.RosenbergJansen@gmail.com

More details on the HEED project can found at http://heed-refugee.coventry.ac.uk

Photo credits: Cover by Cristi Goia, other photos $\odot$ HEED, CEdoardo Santangelo, Coventry University.

The HEED project is funded by the Engineering and Physical Science Research Council (EPSRC) as part of the Global Challenges Research Fund. HEED is led by an interdisciplinary team based at Coventry University, in partnership with the international development charity, Practical Action, and Scene Connect, a social enterprise strengthening communities through the development of ICT products.

This report should be referenced as:

Al-Kaddo, H. and Rosenberg-Jansen, S. (2021) Definitions and Differences: The Evolving Space of Energy Access in Humanitarian Energy. HEED briefing paper, Coventry University UK. DOI: 10.18552/HEED/2021/0003 


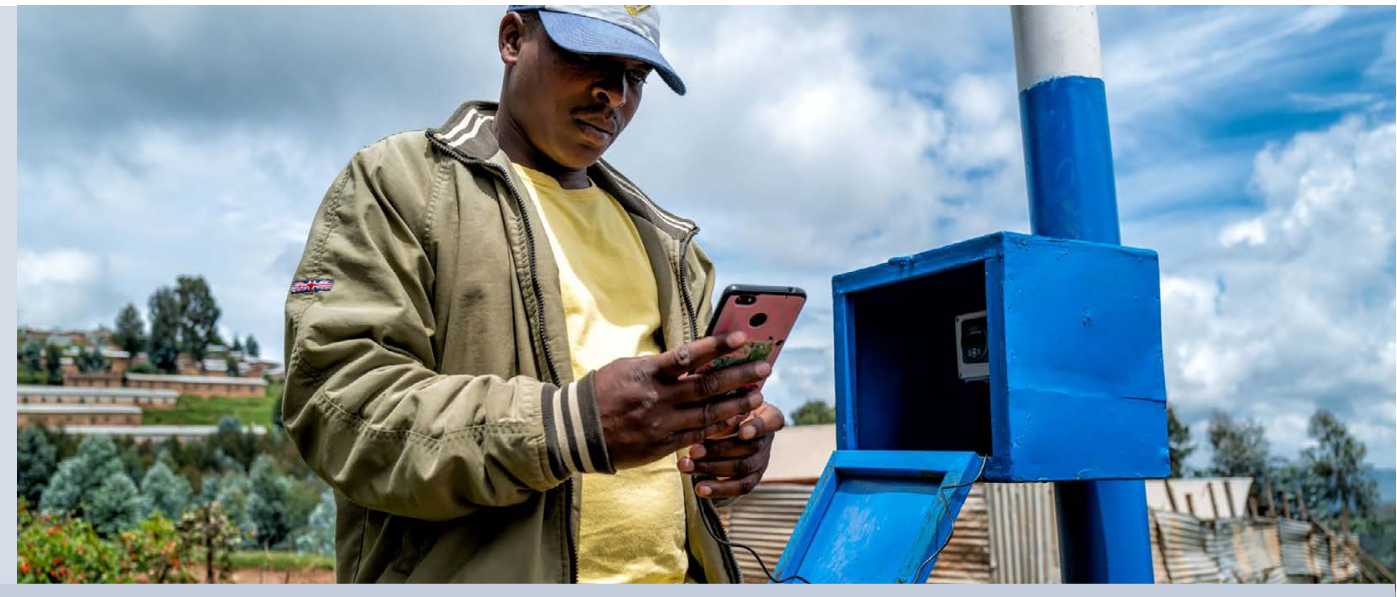

\section{Contents}

Understanding energy for displacement

Definitional differences

Evolution and adaptation of terminology in humanitarian energy

Conclusion 


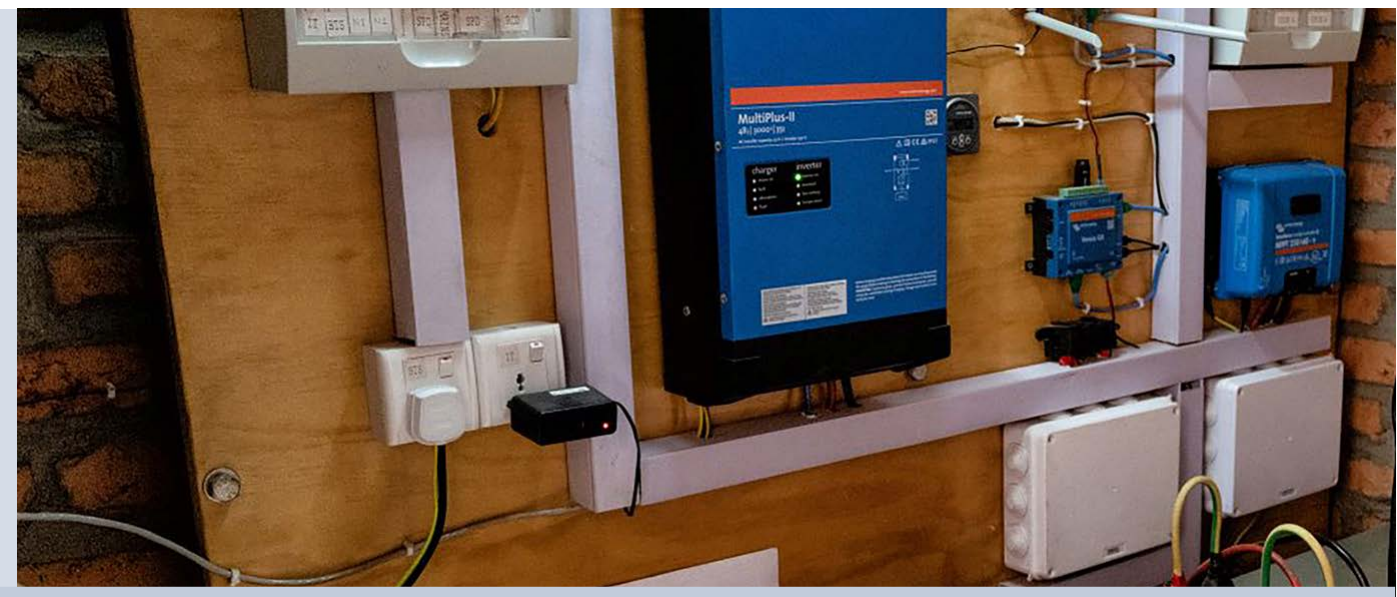

\section{Understanding energy for displacement}

The world faces a growing humanitarian challenge: over 80 million people are now forcibly displaced from their homes by multiple and protracted conflicts (UNHCR 2021). Global crises such as climate change, conflict and natural disaster have meant that over 26 million people have been forced over borders as refugees and 45 million people are internally displaced within their countries. Within this context, displaced people lack access to clean cooking solutions and are often not able to access modern electricity to meet their needs for power, heating and cooling. The realities of living without energy access are extremely challenging (Mercy Corps and GPA 2020). Many people still cook over three-stone fires using firewood and live in the dark at night. Small enterprises run by displaced people are not able to access the energy they need to run their businesses, provide local jobs, or drive local economic development. Community facilities such as schools, hospitals, water, sanitation, and hygiene (WASH) facilities, and refugee community spaces are without reliable power. Humanitarian facilities, offices, compounds and registration spaces use expensive and polluting diesel fuel (Lahn and Grafham 2018). These factors reduce the quality of life of refugees and other displaced people, cause financial and environmental pressures on humanitarian agencies and host communities, and contribute to global climate emissions (UNITAR, 2018).

Displaced communities are being left behind in progress on sustainable development. It is highly likely that Sustainable Development Goal 7 (SDG 7), ensuring access to affordable, reliable, sustainable and modern energy, will not be met for refugees or internally displaced populations (IDPs). However, due to a considerable lack of data and research into the current levels of access of communities, it is difficult to evaluate the true progress being made towards these global targets. The humanitarian system has made repeated, international commitments to improve the lives of displaced people, through the Grand Bargain and the Global Compacts for Migration and Refugees (IASC 2016, IOM 2018, and UNHCR 2018). However, progress on energy remains limited despite these commitments. 
The UN-led Global Platform for Action for Sustainable Energy Solutions in Situations of Displacement (the GPA) aims to support access to sustainable energy by providing a collaborative agenda for concrete actions to ensure that all refugees and displaced people enjoy safe access to affordable, reliable, sustainable, and modern energy services by 2030 . The GPA is supported by academic and research projects, such as the Humanitarian Engineering and Energy for Displacement (HEED) at Coventry University and the Modern Energy Cooking Services (MECS) Programme at Loughborough University, to showcase academic work and analytical evidence on how sustainable energy can be provided for vulnerable communities such as refugees. This paper will explore the topic of humanitarian energy, seeking to understand the different definitions and concepts within the sector.

The humanitarian energy sector has been rapidly developing over the past five years. While initial policy discussions and intervention actions were focused on refugees in camps, the sector now also covers IDPs, as well as the communities who host displaced people (Grafham 2020). To support the development of the sector, this briefing paper outlines a number of commonly used definitions and concepts within the humanitarian energy community and discusses why a number of differences have emerged within terminology for energy access for displaced people. It is hoped that the paper will facilitate discussion among partners and sector stakeholders, and inform consensus on the types of terminology to be used in the future. Aligning and standardising definitions may be a first step in harmonisation across the sector and pushing forward institutional action on sustainable energy at a faster pace than has been possible so far. This paper also offers a timely input for the UN High-Level Dialogue on Energy ( $\mathrm{HLDE}$ ) process which will draw attention to the issue of energy for refugees during Autumn 2021.

The methodology used to develop this briefing paper draws on our experience as practitioners and our work as academics to codify and understand the humanitarian energy sector as it has developed over the past ten years (Rosenberg-Jansen 2020). The paper draws on definitional ideas presented in the book 'Energy Access and Forced Migration' (Grafham 2020) and builds on analytical work from our doctoral research. The definitions presented in the following sections are intended as starting points for discussion, rather than representing formally agreed terms. It is hoped that over time, such definitions can evolve as an 'industry standard' lexicon for humanitarian energy policy and practice. We welcome feedback and discussion of these ideas to further support the development of the humanitarian energy sector. 


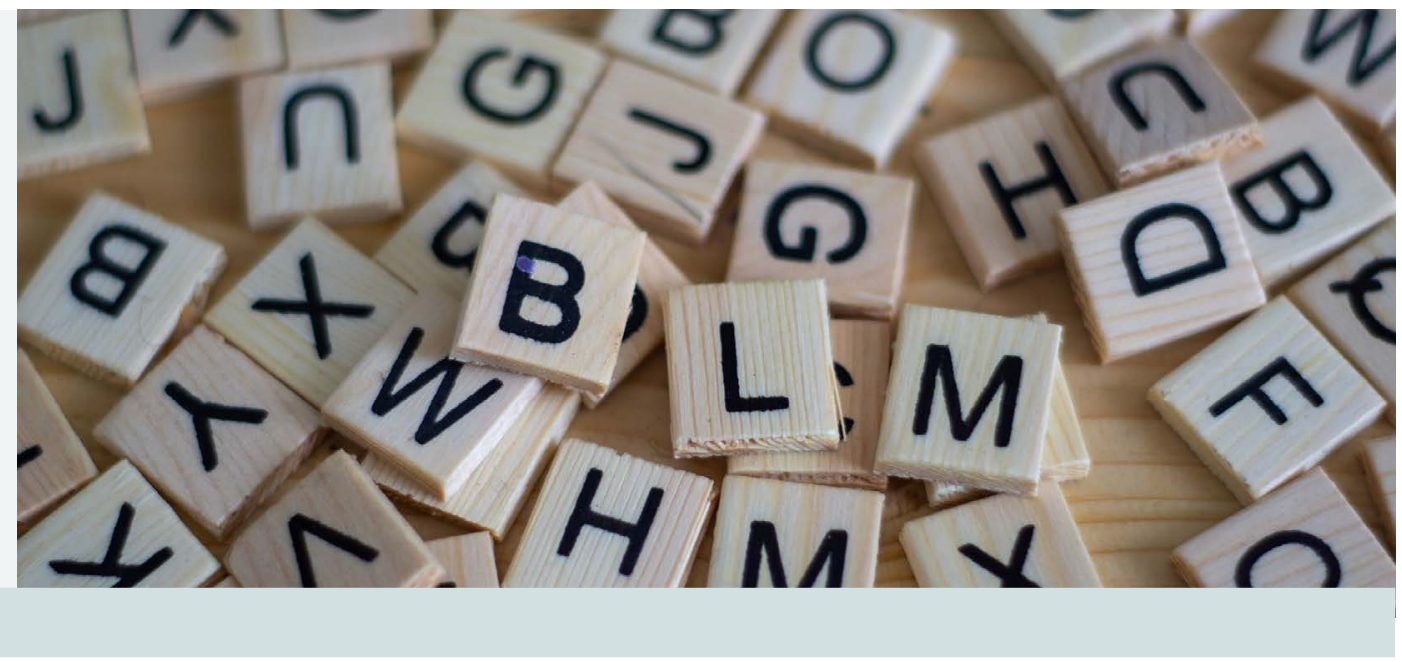

\section{Definitional differences}

Definitions within the humanitarian energy sector are complex and evolving. There are many differences within the community, and ongoing debates and discussions about which terms cover which topics. For instance, definitions from the practitioner perspective are usually used differently depending on use and the energy needs of displaced communities. This paper, in line with the Global Platform for Action (GPA) for Sustainable Energy solutions in Situations of Displacement, takes a neutral view and is open to all definitions. There are two core definitions currently used within the sector:

Humanitarian energy: "Institutions, policies, programmes, global initiatives, actions and activities which use a range of sustainable and fossil fuel energy sources in contexts of displacement, to meet the energy needs of people in camps and urban settings, self-settled refugees, host communities, and internally displaced people". Humanitarian energy covers needs during emergencies and protracted situations, and all populations impacted by war, famine, violence and persecution, climate change, and natural disasters, and can be considered the umbrella term for the sector. From: RosenbergJansen, 2020, p17.

Energy access in displacement settings: Ensuring reliable, sustainable and affordable energy access for all displaced people, including household cooking and electricity solutions, energy for enterprises and community services, and decarbonising energy for humanitarian facilities. Energy for forced displacement covers needs during emergencies and protracted situations, and all populations impacted by war, famine, violence and persecution who are forcibly displaced. Source: this paper.

To some extent these terms are used interchangeably, but some debate suggests that humanitarian energy is more closely linked to development processes, while forced displacement language speaks clearly to traditional humanitarian groups. 
Both definitions support the GPA vision that all "displaced persons, host communities, and associated humanitarian response mechanisms have access to affordable, reliable, sustainable and modern energy services by 2030" that aligns with SDG 7 language agreed by UN member states. Within this context, the term 'humanitarian action' is often used to refer to systems which are based on "principled provision of assistance and protection in order to save lives, prevent and reduce suffering and preserve people's dignity, in crises arising from armed conflict, natural hazards and other causes" (ALNAP, 2021, p5).

Several elements are important to these definitions. Firstly, the inclusion of refugee communities, IDPS, and host communities to ensure that definitions in the sector are inclusive and do not just focus on refugees. The definitions also cover the location of displaced people: whether in camps, settlements, urban or rural locations, and those who are informally or self-settled. Secondly, the terms reflect the principle that action within the sector covers a range of intervention levels - at the field, regional and global levels. These definitions cover a range of initiatives, projects, programmes, and actions both in terms of direct intervention (eg: building a mini-grid or distributing solar lanterns), but also cover policy and coordination activities to build knowledge within the sector. Thirdly, the definitions cover a range of different fuels and solutions, including both fossil fuels and sustainable solutions. While the GPA is aimed at facilitating renewable and sustainable solutions, it is important that sector-wide definitions also include traditional and existing supply mechanisms such as diesel generation and firewood provision in order to capture current practices and sources of energy. This aligns with the

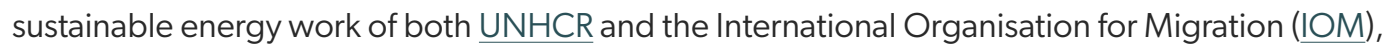
as well as the ideas and concepts discussed within GPA steering group members.

The 'energy access in displacement settings' term outlined above draws directly on the language used for the SDG 7 on energy, which aims to "ensure access to affordable, reliable, sustainable and modern energy for all" (Sustainable Development Goals, 2017). Adapting this language for displaced people is required to provide a specific link between humanitarian approaches and the broader development aims of the SDGs. While in theory SDG 7 includes displaced people, as it refers to 'all' communities, refugees and IDPs have only recently started to be mentioned in SDG reports and processes (World Bank, 2017, p44). As 80 million people are now forcibly displaced (UNHCR 2021), a number which is likely to grow over the coming years, it is increasingly important to draw attention to humanitarian energy needs specifically.

Beyond these two core definitions, several further variations exist. Many of these are outlined in the table below and demonstrate a number of differences within the sector. Historically, energy provision in displacement settings focused on household energy, covering both cooking solutions and lighting for homes. Language on cooking drew heavily from the experience of the Clean Cooking Alliance and previous sectoral work, such as that under the SAFE network. While initial work on electricity focused on household lighting, the sector has now expanded to include the electricity and power needs of households. However, more recent definitions are more comprehensive and include a range of users and technologies. This focus changed within research and policy documents in 2015 with the publication of the Heat, Light and Power paper by Chatham House, which included energy needed for community facilities and enterprises as well as considering the sustainability of energy for humanitarian institutions. In 2021, the sector covers the range of energy solutions and needs of different populations, as outlined in the table below. 
Further definitions on terms used across the sector, for example the use of the terms 'marketbased' and 'delivery models', are provided by the WFP and UNITAR Energy Delivery Models (EDM) training produced during 2020 and 2021. Several organisations, including the Humanitarian Engineering and Energy for Displacement (HEED) project at Coventry University and the Modern Energy Cooking Services (MECS) programme at Loughborough University, have helped to shape these ideas and definitions.

The table below covers a number of specific terms, including:

- Energy for both emergencies and in protracted (long-term) settings.

- Energy for refugees, internally displaced people (IDPs), and for other migrants.

- Renewable, clean, sustainable energy and fossil fuel sources.

- Modern (often electricity and gas sources) and traditional energy (for example, three stone fires, firewood, basic lanterns, etc).

- Access in households, but also energy access for local businesses and enterprises, community facilities, and humanitarian operations and facilities.

- Terms covering policy, management, and the humanitarian-development nexus.

\section{Table 1: Existing terms within the sector}

\section{Commonly used terms}

Overarching definitions

Energy access in displacement settings, energy for displaced people, energy and forced migration

\section{Current scope}

Sector-wide term, holistic and covering a range of displacement contexts. Energy for displacement is often the umbrella and informal term used across settings. Sometimes this term is preferred by humanitarian actors.

\section{Suggested definition}

Ensuring reliable, sustainable and affordable energy access for all displaced people, including household cooking and electricity solutions, energy for enterprises and community services, and decarbonising energy for humanitarian facilities. Energy for forced displacement covers needs during emergencies and protracted situations, and all populations impacted by war, famine, violence and persecution. Inclusive of energy supply and use for all forcibly displaced people: including migrants, refugees in camps and urban settings, and internally displaced people. Host communities and selfsettled refugees can also be included in this definition as their energy needs are impacted by displacement, although these terms normally focus on energy for people in refugee and IDP camps or refugees in urban areas. 


\begin{tabular}{|c|c|c|}
\hline Commonly used terms & Current scope & Suggested definition \\
\hline $\begin{array}{l}\text { Humanitarian energy: } \\
\text { energy access in } \\
\text { humanitarian settings }\end{array}$ & $\begin{array}{l}\text { Sector-wide term, } \\
\text { holistic and covering a } \\
\text { range of humanitarian } \\
\text { contexts. Increasingly, } \\
\text { practitioners are } \\
\text { using the term } \\
\text { humanitarian energy } \\
\text { instead of energy for } \\
\text { displacement to align } \\
\text { explicitly with the } \\
\text { humanitarian sector. } \\
\text { Sometimes this term } \\
\text { is preferred by energy } \\
\text { actors. }\end{array}$ & $\begin{array}{l}\text { "Institutions, policies, programmes, global initiatives, actions and } \\
\text { activities which use a range of sustainable and fossil fuel energy } \\
\text { sources in contexts of displacement, to meet the energy needs of } \\
\text { people in camps and urban settings, self-settled refugees, host } \\
\text { communities, and internally displaced people" (Rosenberg-Jansen, } \\
2020, \text { p17). Including the use of a range of energy sources across } \\
\text { all contexts of displacement, and the energy needs of people in } \\
\text { camps and urban settings, self-settled refugees, host communities } \\
\text { and internally displaced people. Humanitarian energy covers needs } \\
\text { during emergencies and protracted situations, and all populations } \\
\text { impacted by war, famine, violence and persecution, climate change, } \\
\text { and natural disasters. While energy for displacement is often used as } \\
\text { a neutral term, humanitarian energy is often being used to align with } \\
\text { progressive ideals on renewable energy and emerging lessons from } \\
\text { the energy access sector on energy access rights, sustainability, and } \\
\text { leaving no-one behind in the transition to modern energy access. }\end{array}$ \\
\hline Energy in emergencies & $\begin{array}{l}\text { Focused on crisis and } \\
\text { emergency situations, } \\
\text { including natural } \\
\text { disasters and conflict } \\
\text { settings. }\end{array}$ & $\begin{array}{l}\text { The use and supply of energy for crisis situations, including disasters } \\
\text { and conflict settings. Often focused on short-term power and } \\
\text { fuel supplies and the immediate needs of newly encamped and } \\
\text { displaced populations. Energy in emergencies can also cover a wide } \\
\text { range of people, including those who are not displaced from their } \\
\text { region, but are in an emergency in or near their home (for example, } \\
\text { people affected by earthquakes or other disasters). }\end{array}$ \\
\hline Energy and migration & $\begin{array}{l}\text { Focused on people } \\
\text { on the move and } \\
\text { migrants. }\end{array}$ & $\begin{array}{l}\text { The supply for, and use of, energy by migrant communities, including } \\
\text { economic migrants and asylum seekers. Often focused on migrants } \\
\text { to the global north rather than migrants within the global south or } \\
\text { internally displaced people, and linked with climate change and } \\
\text { development narratives. To date limited empirical work has been } \\
\text { done on this topic. }\end{array}$ \\
\hline $\begin{array}{l}\text { Renewable energy for } \\
\text { refugees }\end{array}$ & $\begin{array}{l}\text { Renewable energy } \\
\text { focus usually } \\
\text { supporting refugees } \\
\text { and increasingly host } \\
\text { communities. }\end{array}$ & $\begin{array}{l}\text { The use of renewable, sustainable and replenishable biomass } \\
\text { energy sources in contexts of displacement. This term often is used } \\
\text { in association with refugee camps, as camps are often densely } \\
\text { populated and renewable solutions are often needed within } \\
\text { communities. }\end{array}$ \\
\hline
\end{tabular}

\section{Energy policy and management definitions}

Humanitarian energy policy
National and global policy considerations, including host government priorities on energy and global initiatives to support the development of sustainable energy solutions.
Humanitarian energy policy is the provision of evidence-based energy strategies, targets, goals and frameworks that are focused on populations in need of humanitarian assistance, which can be produced by global humanitarian organisations, NGOs, national host countries, or development organisations. Humanitarian energy policies often cover both micro and macro factors which include environmental sustainability, host country political and legal frameworks and existing energy infrastructures (definition built on the work of Armstrong et al 2016 and Islam 2020). 


\begin{tabular}{|c|c|c|}
\hline Commonly used terms & Current scope & Suggested definition \\
\hline $\begin{array}{l}\text { Energy at the } \\
\text { Humanitarian - } \\
\text { Development Nexus }\end{array}$ & $\begin{array}{l}\text { Considers the } \\
\text { interplay of } \\
\text { development and } \\
\text { humanitarianism, } \\
\text { aimed at bringing } \\
\text { the lessons of } \\
\text { development practice } \\
\text { to humanitarian } \\
\text { systems. }\end{array}$ & $\begin{array}{l}\text { Energy in the humanitarian-development nexus is the bridge } \\
\text { between humanitarian action and development assistance } \\
\text { using renewable, sustainable and modern energy systems and } \\
\text { technologies to develop better support, livelihood, health, } \\
\text { protection and other basic needs for displaced populations. } \\
\text { The nexus is the reliance on humanitarian energy to enable } \\
\text { energy related development initiatives for populations in need of } \\
\text { humanitarian assistance that simultaneously increase funding and } \\
\text { investment opportunities from a variety of traditional and non- } \\
\text { traditional donors and actors. Furthermore, this can be expanded } \\
\text { to include peace, as part of the already established humanitarian- } \\
\text { development-peace nexus. Peace in this context is important as it } \\
\text { enables integrated sustainable and longer lasting humanitarian and } \\
\text { development initiatives for displaced populations. }\end{array}$ \\
\hline $\begin{array}{l}\text { Humanitarian energy } \\
\text { management }\end{array}$ & $\begin{array}{l}\text { New term emerging } \\
\text { to understand the } \\
\text { longer-term and } \\
\text { holistic elements } \\
\text { of energy planning } \\
\text { for displaced } \\
\text { communities. }\end{array}$ & $\begin{array}{l}\text { Humanitarian energy management is a new term referring to both } \\
\text { the usage and application of energy products and services. It } \\
\text { includes the planning and operation of the installation, production } \\
\text { and consumption of energy with the view to enhancing energy } \\
\text { access and energy efficiency measures for end-users. The approach } \\
\text { includes the management of the entire life cycle of energy } \\
\text { technologies, innovations and programmes by stakeholders for } \\
\text { displaced populations. The life cycle includes the raw material } \\
\text { production, technological implementation in the refugee host } \\
\text { country, the political, legal and institutional frameworks available, } \\
\text { the environmental challenges and the needs of the displaced } \\
\text { populations. Other important factors important to the end of the life } \\
\text { cycle include; by-products produced from a waste management } \\
\text { perspective, the access to procurement through local entities, } \\
\text { the evaluation of systems design throughout the production and } \\
\text { implementation of renewable energy systems for populations } \\
\text { (definition building on work of Islam, 2017). }\end{array}$ \\
\hline $\begin{array}{l}\text { Community- based and } \\
\text { inclusive humanitarian } \\
\text { energy processes }\end{array}$ & $\begin{array}{l}\text { Focused on inclusivity } \\
\text { and ensuring } \\
\text { that the voices of } \\
\text { refugees and IDPs } \\
\text { are embedded } \\
\text { fully within policy } \\
\text { and programming } \\
\text { processes. }\end{array}$ & $\begin{array}{l}\text { Humanitarian energy policies and practices which are based } \\
\text { on the needs and priorities of refugees and displaced people: } \\
\text { going beyond participation as a means of engagement to design } \\
\text { programmes and policies with substantive input from refugees and } \\
\text { displaced people. Including approaches which use participatory } \\
\text { methods, community co-design principles, inclusive planning } \\
\text { tools, which are refugee-led or led by displaced communities, and } \\
\text { listen directly to the voices of the displaced to inform policy and } \\
\text { implementation throughout the programme cycle. }\end{array}$ \\
\hline $\begin{array}{l}\text { Sustainable humanitarian } \\
\text { energy approaches }\end{array}$ & $\begin{array}{l}\text { Focused on } \\
\text { all elements of } \\
\text { sustainability: } \\
\text { including } \\
\text { technological, } \\
\text { financial, } \\
\text { environmental, and } \\
\text { societal sustainability. }\end{array}$ & $\begin{array}{l}\text { Approaches which use sustainable thinking to inform long- } \\
\text { term solutions in humanitarian energy. Including technological } \\
\text { sustainability (the use of renewables), financial sustainability (long- } \\
\text { term planning and structures for graduation from aid and grant } \\
\text { mechanisms), environmental sustainability (reducing emissions, } \\
\text { deforestation and pollution), and societal sustainability (improving } \\
\text { the livelihood, health, education, and social outcomes of societies } \\
\text { in the long-term). We take a progressive stance in this definition to } \\
\text { encourage actors to only label projects 'sustainable' when they meet } \\
\text { the above definition. }\end{array}$ \\
\hline
\end{tabular}




\section{Commonly used terms Current scope Suggested definition}

\section{Energy services and uses definitions}

Household energy for

displaced people

Electricity and lighting for displaced households

Cooking and cooking systems in humanitarian settings

Fuel and energy, SAFE access to fuel and energy in humanitarian settings

Energy for displaced enterprises, energy for refugee businesses

Energy for microenterprises in displacement settings
Focus on lighting, mobile charging, heating, cooking, and cooling for homes and households.

Electricity, lighting, power and appliance focused.

Cooking, firewood, and fuel focused.

Focus on fuel and energy: firewood for households and diesel generation for humanitarian response organisations.

Focus on energy for businesses and small enterprises within refugee or displaced settings. An emerging set of terms that may increase in visibility over time.

Focus on energy for micro-businesses and within refugee or displaced communities. A subset of enterprises covered in the definition above.
Ensuring refugees and displaced people in camps, settlements and urban settings have access to energy for their household use, including affordable lighting and mobile charging, safe cooking technologies, low-carbon power for household appliances.

Energy access in homes of refugees and IDPs, including access to products such as lanterns and torches, services such as electricity supply from solar home systems, and sources including individual electrical appliances and connections to mini-grids or local electricity suppliers.

The use of firewood and fuels as energy for refugees and displaced people: the supply for cookstoves, clean cooking technologies and firewood for displaced people.

Sustainable and safe use of firewood and fuels as energy for refugees and displaced people and effective use of energy resources by humanitarian agencies. Term is often used to focus at the household level on provision of fuels for cooking in refugee and IDP homes and often framed in terms of protection needs.

Term used "to encapsulate energy supply and use across end-users, including energy for livelihoods and jobs, small businesses and productive enterprises, and energy to support the functioning of markets and shops within refugee camps, settlements for displaced people, and host communities" (adapted from Rosenberg-Jansen, 2019 , p1). Term inclusive of productive uses of energy which may use larger-scale power, as below, and micro-enterprises such as tailors, hairdressers and mobile phone charging businesses.

As defined by EnDev and Practical Action (2021): “Energy for micro-enterprises: covers a number of elements, including: energyconsumer entrepreneurs - for example, electricity required in hairdressing salons, charging shops; lighting for informal food sellers and other spaces that require electricity to provide a service; restaurants and informal cafes that use cooking fuels and energy technologies to power their needs. Energy supplier entrepreneurs - meaning entrepreneurs that provide energy services. For example, businesses selling lanterns or cookstoves; businesses selling electricity directly through informal mini-grids; mobile phone charging; refrigeration services. Energy entrepreneurs can also provide training or maintenance of energy technologies. Energy economies" of refugee camps and settlements - meaning the informal and formal exchanges on energy within and across markets, trading spaces and businesses within refugee spaces. Energy economies also include the financial and non-financial trading mechanisms supporting energy access for micro-enterprises, as well as being a mechanism for the delivery and supply of energy products and services for displaced people" (p15). 


\begin{tabular}{|c|c|c|}
\hline Commonly used terms & Current scope & Suggested definition \\
\hline $\begin{array}{l}\text { Energy for productive use } \\
\text { in humanitarian settings }\end{array}$ & $\begin{array}{l}\text { Usually focused } \\
\text { on camps, mini- } \\
\text { grid solutions, and } \\
\text { electricity-based } \\
\text { solutions such } \\
\text { as connection to } \\
\text { national grids. }\end{array}$ & $\begin{array}{l}\text { The supply of energy for medium or large sized enterprises in } \\
\text { refugee camps: enabling entrepreneurship to develop within } \\
\text { refugee camps. Often focused on commercial, agricultural, and } \\
\text { industrial activities using electricity services for the production of } \\
\text { goods or provision of services, which consume a considerable } \\
\text { amount of power. }\end{array}$ \\
\hline $\begin{array}{l}\text { Community facilities and } \\
\text { energy for displaced } \\
\text { people }\end{array}$ & $\begin{array}{l}\text { Often focused } \\
\text { on mini-grid and } \\
\text { decentralised energy } \\
\text { solutions. }\end{array}$ & $\begin{array}{l}\text { Providing sustainable and affordable energy to community facilities, } \\
\text { including schools, hospitals, community spaces, and street lighting. } \\
\text { Often focuses on electricity solutions, but can encompass community } \\
\text { cooking initiatives and kitchens. }\end{array}$ \\
\hline $\begin{array}{l}\text { Institutional energy for } \\
\text { humanitarian agencies, } \\
\text { energy for operations }\end{array}$ & $\begin{array}{l}\text { How humanitarian } \\
\text { organisations and } \\
\text { their partners access } \\
\text { energy, how much is } \\
\text { consumed and the } \\
\text { cost of energy within } \\
\text { operations }\end{array}$ & $\begin{array}{l}\text { The supply of energy for humanitarian agencies, NGOs and } \\
\text { implementing partners working in refugee camps, displacement } \\
\text { settings, and crisis response situations. Focused on electricity } \\
\text { products and services: currently most operations use diesel fuel to } \\
\text { power their operations. }\end{array}$ \\
\hline Solarising operations & $\begin{array}{l}\text { Focused on camps, } \\
\text { grid-level connection } \\
\text { services or and mini- } \\
\text { grid solutions using } \\
\text { solar energy. }\end{array}$ & $\begin{array}{l}\text { The supply and development of solar energy solutions for } \\
\text { humanitarian power sources, including energy needs for offices and } \\
\text { compounds, registration centres and core humanitarian spaces. } \\
\text { Often referring to the move to replace diesel generators with } \\
\text { renewable and solar solutions to reduce emissions, cut costs, and } \\
\text { improve the sustainability of UN operations. }\end{array}$ \\
\hline
\end{tabular}

Table: Adapted from Rosenberg-Jansen, 2020 (in Grafham, 2020, Energy for Forced Migration). 


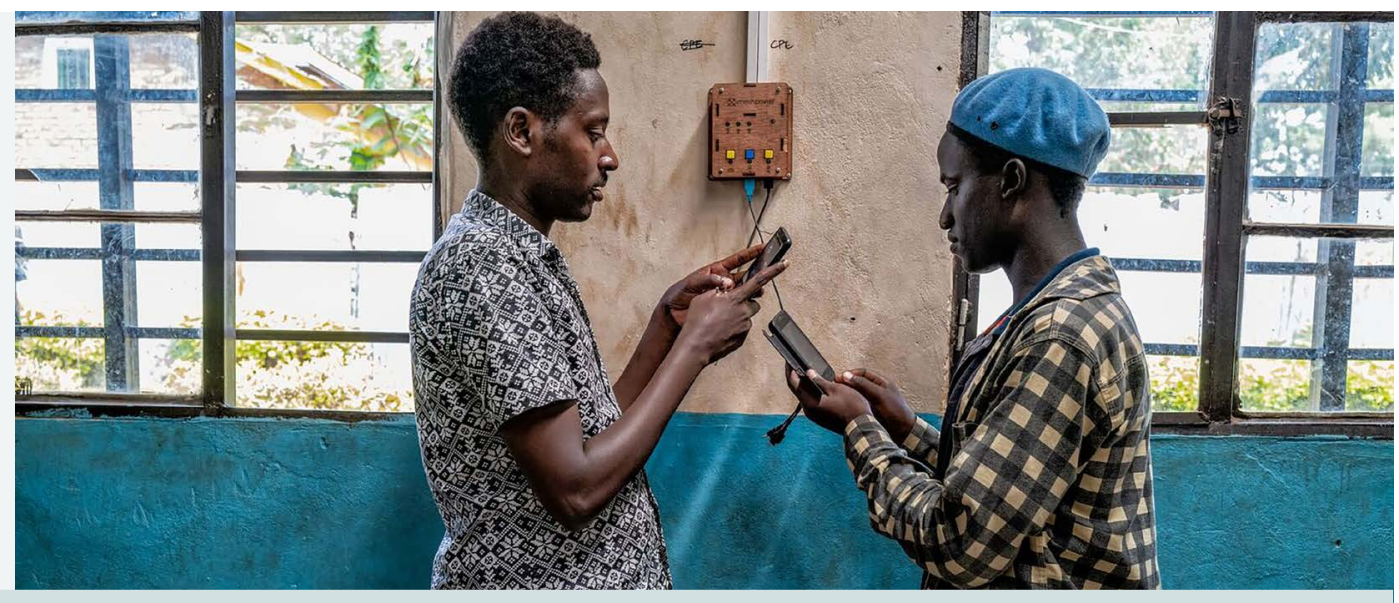

\section{Evolution and adaptation of terminology in humanitarian energy}

The table above provides some sense of the scope of humanitarian energy, both in terms of the depth and breadth of the terms used. We can consider the different sections of the table as.

- Overarching terms used across the sector: these terms reflect that a mix of ideas are outlined to reflect the different terms used and discussed by sector participants. These differences do not reflect our views as academics, but rather the realities of a sector still in the emergent process of defining itself. As an example, different actors may choose to use the terms 'energy in displacement settings' as opposed to 'humanitarian energy' due to the perceived differences of these terms to connect with the core audiences that actor is speaking to.

- Energy policy and management terms: Many of the terms outlined in this section of the table are currently unwritten perceptions or understandings within the sector, but to date have largely been un-codified in academic or practice literature. As a result, this briefing paper offers a concrete suggestion on what such terms could mean and a sense of how they are used within humanitarian energy spaces. These terms build on existing terminology developed within the energy access or management literature, to consider how such thinking applies in humanitarian contexts.

- Energy services and use definitions: the definitions can demonstrate the different focus areas of certain policies or programming interventions. For example, the coalition of some actors around the term 'SAFE' (Safe Access to Fuel and Energy), compared to those who use the term 'cooking systems' implies both a shift in focus from the physical safety and health benefits of clean cooking, to considerations of the holistic approach to understanding cooking needs in displacement settings. 
Within the complexity presented in the table above, it is clear that the humanitarian energy sector is evolving. Terminology that was relevant five years ago, such as the use of the term SAFE, has now largely been discarded in favour of terms centred on the population in need - for example, energy for the displaced and energy for refugees. The 'energy use' terms outlined in the third section of the table suggest how the sector has evolved to develop semi-structured 'sub-sectors' to separate and identify the energy needs of households compared to energy needs of community facilities or in humanitarian operations. Many of the ideas presented within this paper overlap and definitions do not have strict bounded remits. The evolution of definitions has often caused confusion within the sector on the precise focus and remit of different initiatives. It is hoped that this paper may contribute to clearer understanding and ongoing debate on the evolution of concepts and programming in humanitarian energy.

As well as evolving, so too has the sector adapted, changing its focus to align with global initiatives and policy focus areas as they have emerged. For example, renewed policy and donor focus on livelihoods and jobs has led to the creation of a subsection of activity and terms on energy and micro-enterprises and energy for refugee business. Further policy analysis could be undertaken to understand how such changes happen and identify the drivers underpinning alterations in terminology within the sector. 


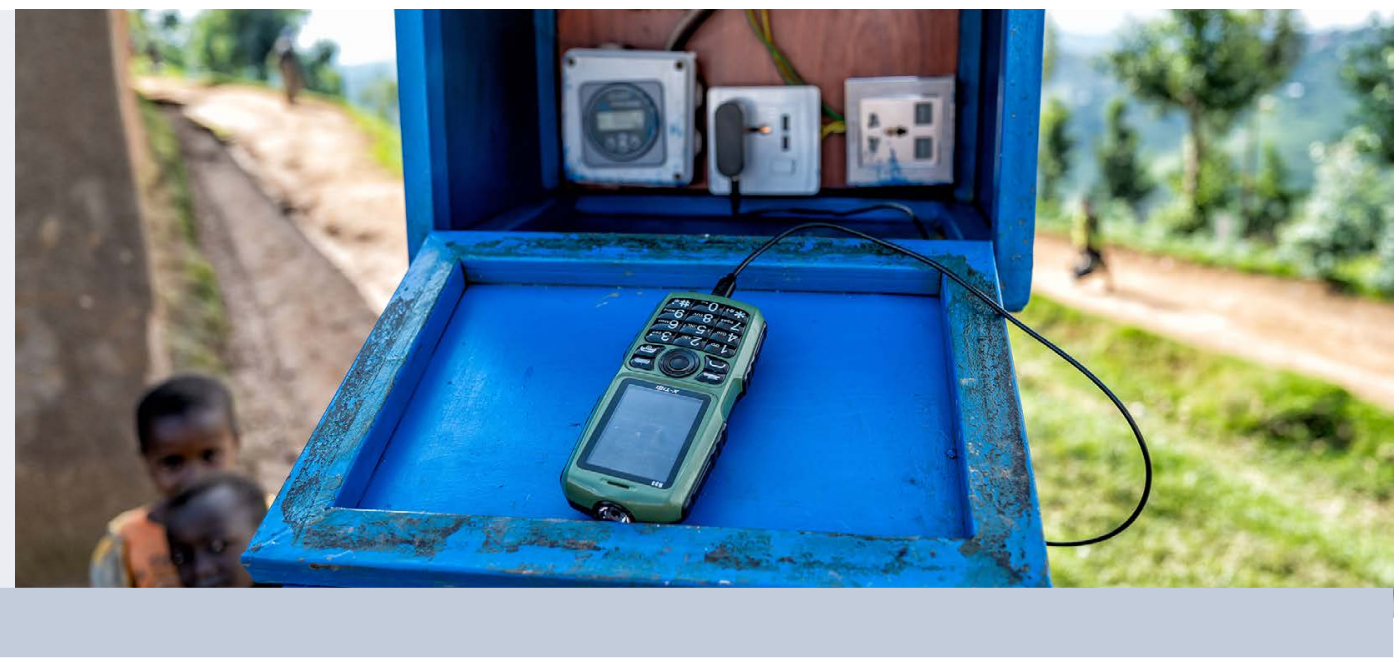

\section{Conclusion}

The humanitarian energy sector will continue to evolve and change over the coming years. Definitions on energy use and supply are likely to expand and change focus. This paper provides a sense of the state of play within the sector in 2021, and may offer some possibilities for consolidation by actors who are often divided both by terminology and by perceived remits of institutions.

While our work has suggested a number of academic definitions to support the development of the sector, it is important to note that changes are often driven by practitioners and policymakers who are tailoring terms and solutions depending on the needs of displaced people and specific displacement contexts. As a result, it is likely that these definitions will evolve and change further over the coming years. Additionally, this paper focuses on the overarching terminology surrounding the sector, however, much work still needs to be done on precise terms and data definitions. Initial work to provide concrete discussion on measurable indicators for humanitarian energy has also been developed by the GPA community and a summary is online (Rosenberg-Jansen and Bisaga 2020).

Further academic analysis of the history and governance of humanitarian energy is needed to fully understand the roles and responsibilities present within the sector, as well as to provide commentary on the evolution of ideas that inform both policy and practice in the humanitarian energy space. The authors encourage responsible research that is applicable to the needs of displaced populations using the most recent research gaps and analysis produced by the GPA in 2021. 


\section{Bibliography}

Armstrong, R.C., Wolfram, C., De Jong, K.P., Gross, R., Lewis, N.S., Boardman, B., Ragauskas, A.J., Ehrhardt-Martinez, K., Crabtree, G. and Ramana, M. (2016). The frontiers of energy. Nature Energy, 1: 1-8. doi: 10.1038/nenergy.2015.20

Burke, M.J. and Stephens, J.C. (2017). Energy democracy: Goals and policy instruments for socio technical transitions. Energy Research \& Social Science, 33: 35-48. doi: 10.1016/j.erss.2017.09.024

ALNAP (2021). The state of the humanitarian system fifth edition: Inception report. London: ALNAP.

Coventry University (2017). HEED Project: Humanitarian Engineering and Energy for Displacement.

ENDEV and Practical Action (2021). Learning \& Innovation: Humanitarian Energy Energy for microenterprises in displacement settings. ENDEV Report.

Fanning, E. and Fullwood-Thomas, J. (2019). The Humanitarian-Development-Peace Nexus: What does it mean for multi-mandated organizations? Oxford: OXFAM.

Global Alliance for Clean Cookstoves (2013) SAFE: Energy access in humanitarian settings. Global Alliance for Clean Cookstoves, Washington, DC, USA.

GOGLA (2021). About us. GOGLA.

Grafham, O. (2020). Energy access and forced migration, 1st Edition. Grafham, O. [Ed]. London, UK: Routledge.

Hövelmann, S. (2020). Triple nexus to go: Humanitarian topics explained. Berlin, Germany: Cha Maecenata Stiftung.

IASC (2016). The grand bargain. Inter-Agency Standing Committee (IASC).

IOM (2018). Global compact for migration. International Organization for Migration.

IOM (2021). Migration, Environment and Climate Change (MECC) Division. International Organization for Migration.

Islam, M.M. and Hasanuzzaman, M. (2020).Chapter 1 - Introduction to energy and sustainable development. In: Hasanuzzaman, M.D. \& Rahim, N.A. (Eds.) Energy For Sustainable Development. Academic Press.

Lahn, G. and Grafham, O. (2015). Heat light and power for refugees: saving lives, reducing costs. London UK: Chatham House.

Lahn, G. and Grafham, O. (2018). The costs of fuelling humanitarian aid. London, UK: Chatham House.

Lie, J.H.S. (2020). The Humanitarian-development nexus: Humanitarian principles, practice, and pragmatics. Journal Of International Humanitarian Action, 5: 18. doi: 10.1186/s41018-020-00086-0

Mercy Corps and GPA (2020). Realities of life without access to energy (video). Global Plan of Action. . 
MEI (2017). Moving energy initiative - resources. London, UK: Chatham House.

Redvers, L. (2019). Searching for the nexus: priorities, principles, and politics. The New Humanitarian. Redvers, L. \& Parker, B. (2020). Searching for the nexus: Give peace a chance. The New Humanitarian. Rosenberg-Jansen, S. (2020). Voices in the dark: energy and the politics of living in refugee camps. DPhil thesis. University of Oxford. Oxford, UK.

Rosenberg-Jansen, S. (2020). Leaving no-one behind: Global governance of energy in the humanitarian sector. In: Grafham, O. (Ed.), Energy Access and Forced Migration. London UK: Routledge.

Rosenberg-Jansen, S. (2019). Rethinking energy economies for refugees.

Rosenberg-Jansen, S., and Bisaga, I. (2020). GPA workshops in July 2020: Data and indicators for global and project humanitarian energy needs. Geneva, Switzerland: Global Plan of Action. GPA.

Rosenberg-Jansen, S., and Haselip, J. (2021). Critical concepts and research needs in humanitarian energy. UNEP-DTU GPA Working Paper 202. Geneva, Switzerland: Global Platform of Action (GPA).

Sustainable Development Goals (2017). SDG Goal 7: Sustainable Development Knowledge Platform.

UNHCR (2018). UNHCR - The global compact on refugees.

UNHCR (2019). Global strategy for sustainable energy. UNHCR.

UNHCR (2021). UNHCR - Refugee statistics 2021. The United Nations High Commissioner for Refugees (UNHCR).

UNITAR (2021). The GPA in 2020 - Global Platform of Action.

WFP and UNITAR (2021). Energy Delivery Models. Module 1 Training.

World Bank (2017). Global tracking framework: Progress toward sustainable energy. Washington, DC: World Bank. 


\section{Humanitarian Engineering and Energy for Displacement (HEED)}

Since the introduction of the UNCHR global strategy on Safe Access to Fuels and Energy (SAFE) in 2014, humanitarian responses to refugees and internally displaced people (IDPs) have sought to deliver safe and sustainable energy provision. By focusing on the lived experiences of refugees and IDPs in Nepal and Rwanda to understand energy usage in refugee camps and settlements, the HEED project will develop, and contribute to, innovative responses which address demands for improved energy services.

Our research, led by key experts in the fields of engineering and social science, is looking for solutions that will provide crucial guidance on creative approaches and technologies to clean or fuel-efficient cookers, alternative and sustainable fuels, and solar-powered lighting, which will build the resilience of refugee communities.

\section{Our partners}

The HEED project, is led by an interdisciplinary team based at Coventry University, in partnership with the international development charity, Practical Action, and Scene Connect, a social enterprise strengthening communities through the development of ICT products.

\section{$\triangle$ Contact us}

www.heed-refugee.coventry.ac.uk

This research has been funded by the EPSRC Global Challenges Research Fund (Grant N EP/P029531/1).

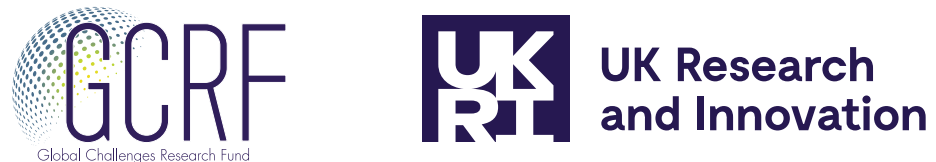

